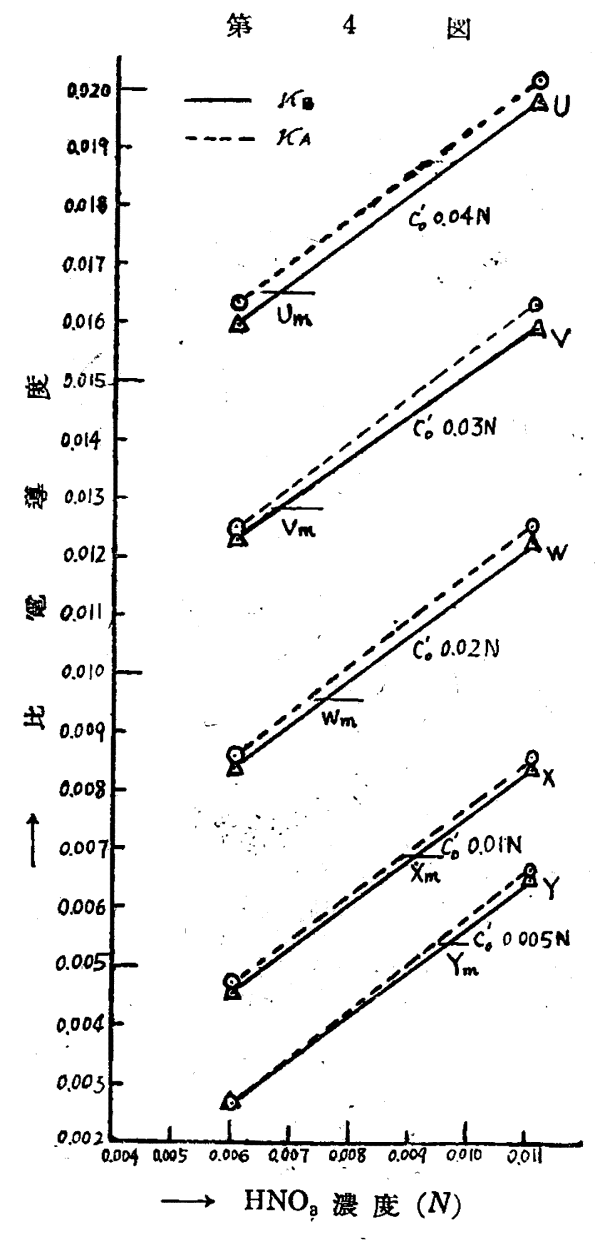

\begin{tabular}{lccccc} 
& \multicolumn{2}{c}{ 第 } & 2 & 表 & \\
$c_{\mathrm{o}}^{\prime}(N)$ & 0.04000 & 0.03000 & 0.02000 & 0.01000 & 0.00500 \\
$K \times 10^{-2}$ & 0.45 & 1.02 & 1.77 & 1.84 & 2.92
\end{tabular}

即ち反底モル比 $2 / 1$ とせる場合に比して $1 / 1$ とせる場合は $K$ の 傾は $\mathrm{HCl}$ の初涨度の变化に対して著しく一致が良くなつている。 從つて $N / 100$ 附近の混合溶液に於ては, その本衡狀態は (1)に
よつて表わし難く,（2）によるのが妥当である。

\section{III. $\mathrm{Cl}_{2}$ の加水分解度と平衡恒数}

$\mathrm{Cl}_{2}$ の加水分解恒数は前報に揭げた如く

$$
K_{1}=\frac{\left[\mathrm{H}^{\cdot}\right]\left[\mathrm{Cl}^{\prime}\right][\mathrm{HClO}]}{\left[\mathrm{Cl}_{2}\right]}=4.7 \times 10^{-4}
$$

でむるので，これより各浪度に於ける $\mathrm{Cl}_{2}$ の加水分解度 $x$ を計 算して見ると，

$$
\begin{array}{lccccc} 
& \multicolumn{2}{c}{\text { 第 }} & 3 & \text { 表 } & \\
c_{0}{ }^{\prime}(N) & 0.04000 & 0.03000 & 0.02000 & 0.01000 & 0.00500 \\
x(\%) & 25 & 37 & 56 & 79 & 90
\end{array}
$$

$x$ の值は $N / 10$ 附近の場合の $0.65 \sim 9.8 \%$ (前報参照) に比し て著しく大で, 且つ $\mathrm{HCl}$ の初濃度の減少と共に增大している。 從つて $N / 100$ 附近の混合溶液の平衡を考竞る時は $\mathrm{Cl}_{2}$ の加减分 解を無視することは出來ない。而して $x$ の大なる範囲では, $\mathrm{Cl}_{2}$ が加水分解しているとして，本衡を考えるのが荌当をあり，文本 衡恒数は第 2 表の如く， $c_{0}^{\prime}$ の変化につれて，変異灾生ずる等で ある。

以上の計算に於て，垁驗範囲內の條件で， $\mathrm{HNO}_{\mathrm{g}}$ 及び $\mathrm{HClO}$ の 電離度はそれぞれ（1.1〜3.3)×10-2，(1.6〜 5.0) ×10-8 である ので，その影響を無視した。

\section{IV. 総 括}

$N / 100$ 附近の $\mathrm{HCl}, \mathrm{HNO}_{\mathrm{a}} \cdot$ の混合溶液り比電導度の湘定より 本衡濃度文び本衡恒数を計算し，

$N / 10$ 附近に於ては, 平衡狀態が下式で表わされたに対して, $2 \mathrm{HCl}+\mathrm{HNO}_{3} \rightleftarrows \mathrm{HNO}_{2}+\mathrm{Cl}_{2}+\mathrm{H}_{2} \mathrm{O}$

更に $N / 100$ 附近に於ては,

$$
\mathrm{HCl}+\mathrm{HNO}_{\mathrm{s}} \rightleftarrows \mathrm{HNO}_{2}+\mathrm{HClO}
$$

で表わされるに至る。

$\mathrm{Cl}_{2}$ の加水分解度の計算結果は，この結果とよく一致した。 本研览は叹井湾教授の指遵の下に行われた。ここに厚く感謝の 意を表する。

（果京大学生连技術研究所）（炤和 25 年 10 月 11 日受理）

（130）複屈折を利用した硫化亞鉛螢光体の研究（第 1 報）

\title{
$\mathbf{X}$ 線解析亡の関係及び燒成條件と結晶型に就いて
}

\author{
卡木栄次・白井ひて子子
}

\section{-1. 緒論}

硫化亞鉛螢光体の結晶構造と螢光との関係を調べる研究として 垿光顯微鏡を利用して見た所，その結晶構造を直ちに知る事が出 來, 更にX線に依る結果と比較する事により面白い結論か得られ た。硫化亞鉛はよく知られている如く二つの結晶系を有する。第 Iは閃亞鉛鉱で等方晶禾に属し，第2 は織維亞鉛鉱（ウルッ石）
で六方晶系に属する。故に結晶光学の方より見ると閃丕鉛鉱は等 方性にて光輯を有せず，值交ニコルの中にてる滑光する事方無い のに対し,纖維亞鉛鉣は一軸珄 $\left(1\left(\mathrm{~N}_{0}=2.356 . \mathrm{Na}, \mathrm{Ne}_{\mathrm{e}}-\mathrm{N}_{0}=0.022\right)\right.$ 結晶で直交ニコルの中にてよく消光する事になる。即ち偏光顯微 鏡を用いて複屈折を見る事により，閃亞鉛鉣型か，纖維亞鉛鉣型 かを直ちに区別がつくのである。同じ試料の粉末X線䢙折写崸と 比較して見ると，はつきり一致を示し，ウルッ石型と閃亞鉛鉱型 
の混合物に於ても本行関俰がある。從つてこの方法のみで結晶形 の割合を定める事が出來るのである。

燒成の方法と結晶形の関係，螢光，残光の結晶形との関係を種 及研究した結果を少し縕めてみた。

\section{2. 研究の方法}

溃燐光体の結晶は普樋その製造方法（及改応用方法）の上から して余り大きな結晶は得られず, 殆どが数 $\mu$ より数十 $\mu$ の範囲 である。故にデルトランドレンズを使い，集光する光を用5る事 は行い、難いが，本行の偏光を用 5 る方法が適する。用いた㙷微鏡 は島津の鉣物旿微鏡で, 偏光子, 検光子の方向は昇華して作つた 硫化亞鉛（ウルッ石型）を用いて，対眼レンズの十字線と合せて 用いた。倍率は大体 $10 \times 6$ でよく，特に細かいのは $30 \times 10$, 又 結晶粒の大きさを見るには $10 \times 8$ (micro）を用いた。

硫化亞鉛篮光体又は原料粉末を，少量スライドグラスに取り， バサムをつけて，カパーグラスで覆う常法通りにして,プレパ ラートを作る。これはバルサムに埋めると，消光するのが良く見 られるからである。こうして作つたプレパラートを顯微鏡にかけ て，視野を合せてのぞき作ら，プレパラートを趣転して，洞光を 調べるのである。普通の結晶では偏光子に平行，及び直交の位置 にて暗く見え，その間の位置にて明るく見点る。然し大きい結晶 では青及び橙色に着色する場合るある。試料に依つては消光する ものと，消光しないものとが混合している事が多い。故に視野中 の硫化亞鉛を全部写生して，その中の滑光するものを数えてその 割合を定める。1 箇所では㟪差を招く事もあるので， 2 箇所更*

\section{第 2 図 顯 微镜写㵓}

(a)

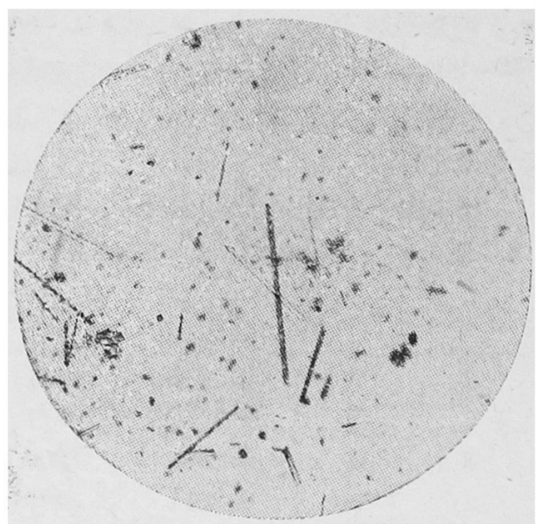

a 年華硫化亞鉛, 直交=コル(10×6)（プロたス）

\section{3. 偏光㬎徽鏡からの結果}

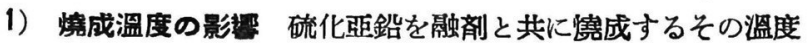
を種々变化した時の模栐を調べて見た。溫度は普通㶰內の溫度を 示し，誤差は $\pm 10^{\circ} \mathrm{C}$ 以內に保つ樣にした。その結果は第 3 四の 橡になる。 $\mathrm{KZ}$ は硫化亞鉛に $\mathrm{KCl} 10 \%$ を加古, 各溫度で 30 分 燒成し, 急熱急冷（炬外冷却）したもの，KC は硫化亞鉛 $1 モ ル$ に対し $\mathrm{KCl} 10 \%, \mathrm{Cu} 0.00005$ モル加えて 30 分熆成し急熱急 冷したすである。 KA は KCl 10\%，Ag 0.00005 モルを加兄 30 分念䓡急泠したものである。

2）燒成時間の影㗽 CF 23〜27 は硫化亞鉛に KCl $10 \%$ 0.00001 モルのCu を入れて $1000^{\circ} \mathrm{C}$ にて急熱急冷したるのであ

*は3籄所を調べて本均する。

こ5して第1困（a）の粶にスケッチして滑光 (extinction)す る粒子の数の割合を消光率として計算するものである。

第 1 図 (a)

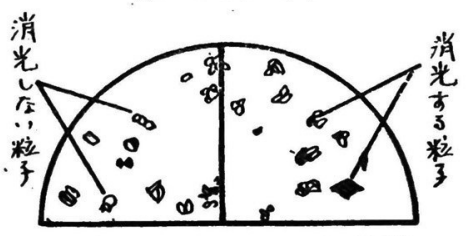

$1200^{\circ} \mathrm{C} 1$ 時間 $\mathrm{ZnS} 10 \% \mathrm{KCl}$

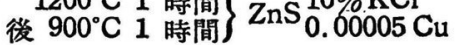
第 1 図 (b)

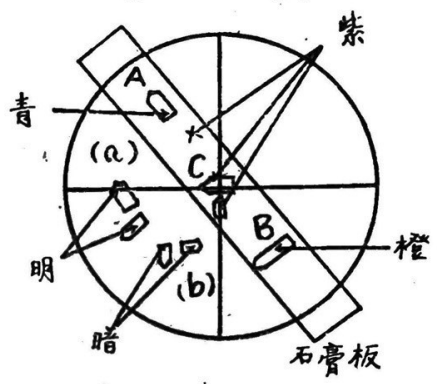

方法の第二としては, 洞 光角を定めるのに用いられ る銳感色板 (sensitive tint plate) 即ち石育板（gypsum）を用いる。これは第 一头の堇の干步を起す厚さ に作られている。(red 1 st order と記したるの)これ をニュルに対し $45^{\circ}$ の位置 に入れると䚇野は荲にな り, ウルッ石型の結晶は今 汽第 1 図 (b) の（a）の位 置で明るく(b) で暗く消光 していたのか，Aで青色， Bで橙色（結晶無色なら赤 色と思了が硫化亞鉛は淡黃 色なる簈めと思われる） C で外の色と混じ堇色になる。この色の变化は非常に敏感で, 普通 の消光にて制り難い細かい結晶に就いても,変化があるかないか を識別し得る。この方法は顯微鏡写冥 (a)，(b) の樣に撮つて調 べてもよいが, 天然色写㣀に依り更に好結果が得られると思われ るので目下実驗中である。

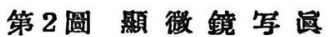

(b)

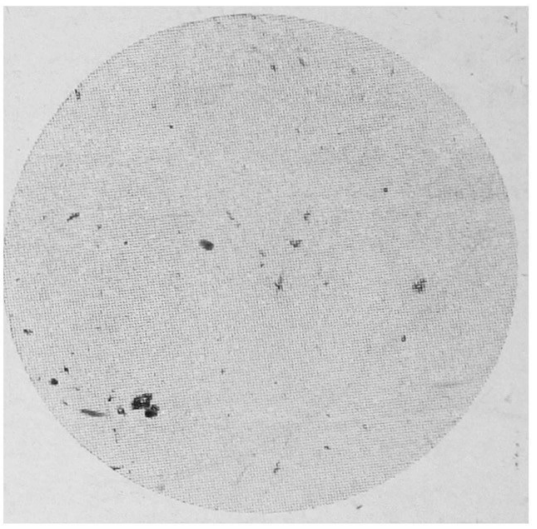

b 年華硫化亞鉛，平行=コル $(10 \times 6) （ フ^{\circ} ロ$ セ）

る。この時には $1000^{\circ} \mathrm{C}$ 附近では, 溫度の影響が大きいから(Sch-

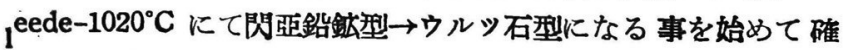
定した。) ${ }^{2}$ 温度の僅少な变化も充分注意する必要がある。又この 條件は後述の樣に融昘の量に低つてむ変化する故, この條件につ いてのみ云える事である。この條件では大体 30４0 分で変化の 最大值に達する。

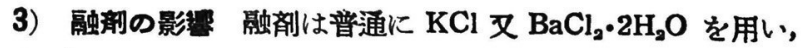
又他のハロゲン化物も用いられるが KCl に就いてその量の影管 をみた。 KC No. 10〜15 は硫化至鉛と KCl を乳錸でつぶじ, CuSO $45 \mathrm{H}_{2} \mathrm{O}$ を $0.1 \%$ の液にして加え乳狀にして罶汼し，それ

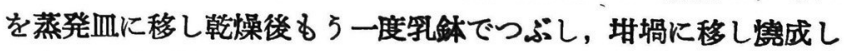
たもの。KZ No.11〜16 は ZnS に KCl を加え水は加えずその 


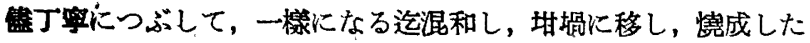
すのである。翼成の程度がこの混和にも相当起因する事がここに あ現われている。

第 3 図䛜成溫度に依る消光幽の変化

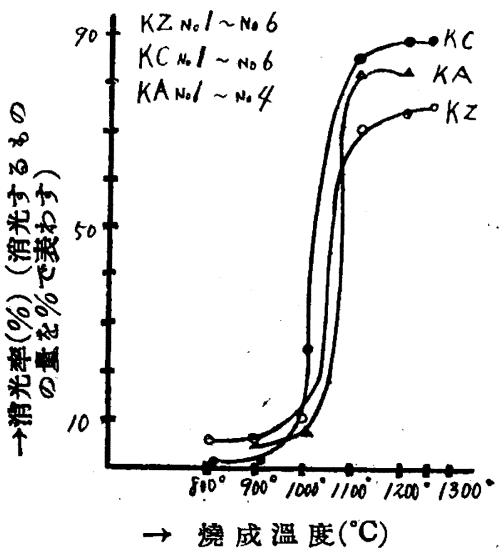

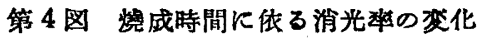

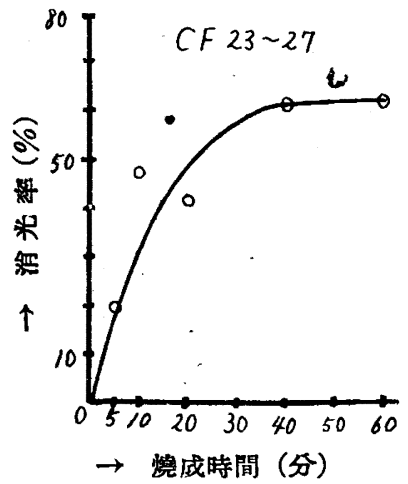

第 5 図 蜃郕量と消光率の関保

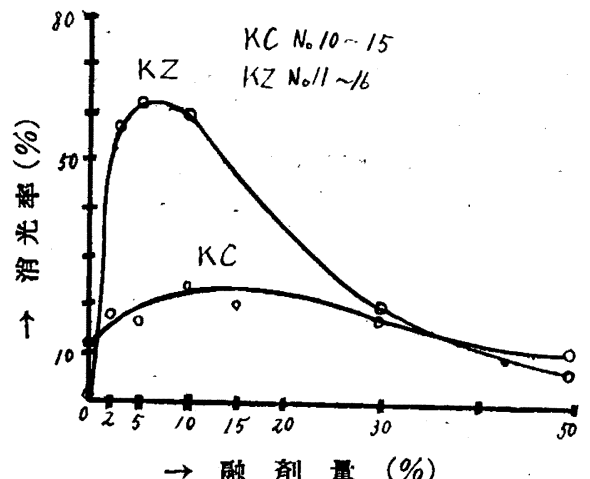

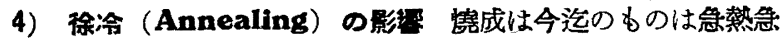
冷(室泒にて直ちに放冷する)であつたが急熱徐冷（炉中で電氣を 切つて余熱で徐々に冷えるすの）あ行つて見た結果，第 4 図の如 き結果であつた。 $1100^{\circ} \mathrm{C}$ 以上の結果か低いのは転位点 $\left(1020^{\circ} \mathrm{C}\right)$ 以下の比較的高溫で長く置かれる結果, ウルッ石型か閃亞鉛鉱型 に送るとも考えられた。そこで $1200^{\circ} \mathrm{C} て ゙ 1$ 時間㙼成して殆んど (90\%以上)ウルッ石型になつた炳光体をその缂 $900^{\circ} \mathrm{C}$ にて, 1 時間堯成して見た。その結果は殆んどウルッ石型の萧で残つてい るので， $1200^{\circ} \mathrm{C}$ で㥁いた他の一部を水洗し，充分粉碎3) し更に $\mathrm{KCl} 10 \%$ を加え， $900^{\circ} \mathrm{C}$ に2 時間琴成して見た。その結果殆 ど全部ウルッ石型であつた。これは原料の硫化亞鉛を $900^{\circ} \mathrm{C} て ゙$,
2 時間辡成した全く閃亞鉛鉱型の螢光体と，完全に異る事を示し た。これ等の点はもつと精細伅調べる必要があろう。

第 6 図冷却速度に依る消光河の変化

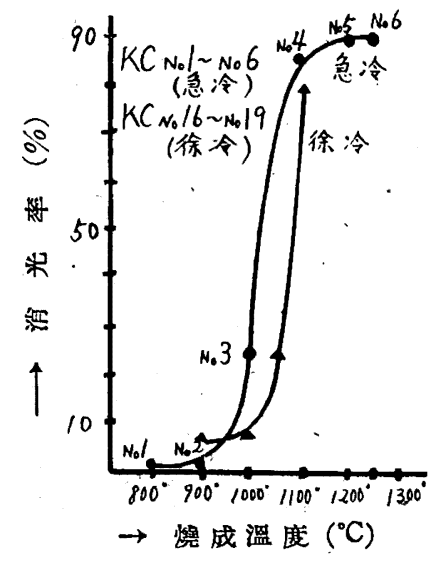

\section{4. 粉末 X 線廻折写䁇との比較}

今迄，硫化亞鉛の結晶の 2 種ある事; 螢光体に於てむ 2 種あり 共に螢光も残光もある事等研究されて來たが，それ等は全部 $\mathrm{X}$ 線 解析に依つてであつた4)。偏光䫝微鏡に依り、複屆折を見れば,粒子 一つ一つが何れかの結晶系か制別出來, 更に結果 1)の樣に定量が 容易である。今迄のX線解析と比較実驗して見ようと考えたがX 線の方は完全な定量は困難であつた。唯定性的に KC No.1, No. 2…No. 6 等を撮つて解析して見た。その結果; No. 1, No. 2 の線は完全に閃亚鉛鉱型䛨りであり No. 4, No. 5, No. 6 は殆 どウルッ石型許りで, 文 No. 3 では丁度閃亞鉛鉱の線もウルッ 石の線む同じ程度現われている事がはつきりした。前の第6因を 見ると消光率が No. 1, No. 2 では 1〜2\%, No. 4 No. 6 は 約 86〜90\%, No. 3 は 25\% で今のX線解析と完全に一致する。 解析の一例を第1表に示す。（約 20 本の線の內，角度の小さな 8 本を示す)

第 1 表（対陰極 $\mathrm{Cu}, 60 \mathrm{kV}, 6 \mathrm{MA} . \exp .2 .5 \mathrm{hr}$ )

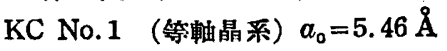

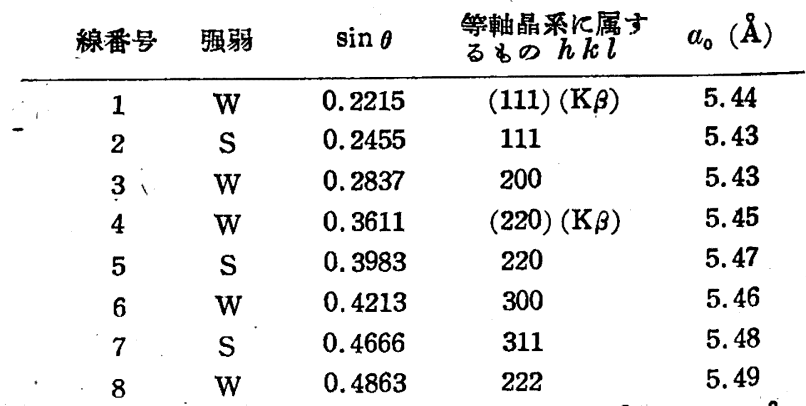

KC No. 6 (六方晶系) $c / a=1.63 a_{0}=3.85 \AA c_{0}=6.28 \AA$

\begin{tabular}{ccccc} 
線番号 & 强弱 & $\sin \theta$ & $\begin{array}{c}\text { 六方晶采K属す } \\
\text { 万多kl }\end{array}$ & $a_{0}(\AA)$ \\
\hline 1 & $\mathrm{~W}$ & 0.2128 & $(100)(\mathrm{K} \beta)$ & 3.78 \\
2 & $\mathrm{~S}$ & 0.2331 & 100 & 3.87 \\
3 & $\mathrm{~W}$ & 0.2464 & 002 & 3.84 \\
4 & $\mathrm{~S}$ & 0.2633 & 101 & 3.82 \\
5 & $\mathrm{~W}$ & 0.3041 & $(102)(\mathrm{K} \beta)$ & 3.86 \\
6 & $\mathrm{~S}$ & 0.3376 & 102 & 3.85 \\
7 & $\mathrm{~W}$ & 0.3619 & $(110)(\mathrm{K} \beta)$ & 3.85 \\
8 & $\mathrm{~W}$ & 0.3923 & $(103)(\mathrm{K} \beta)$ & 3.85
\end{tabular}


KC No.3 (等糔晶系 十 六方晶系)

(等軸晶系) $a_{0}=5.45 \AA$ (六方晶系) $a_{0}=3.86 \AA c_{0}=6.29 \AA$

\begin{tabular}{|c|c|c|c|c|c|c|}
\hline 線番是 & 雖 & $\sin \theta$. & 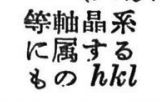 & $a_{0}(\AA)$ & $\begin{array}{l}\text { 六方晶系 } \\
\text { に属する } \\
\text { \&の hlkl }\end{array}$ & $\alpha_{0}(\AA)$ \\
\hline 1 & $\mathrm{~W}$ & 0.2125 & & & $(100)(\mathrm{K} \beta)$ & 3.78 \\
\hline 2 & $\mathrm{~W}$ & 0.2238 & $(111)(K \beta)$ & 5.38 & & \\
\hline 3 & W & 0.2357 & & & 100 & 3.78 \\
\hline 4 & $\mathrm{~S}$ & 0.2453 & 111 & 5.43 & & \\
\hline 5 & $\mathrm{~W}$ & 0.2616 & & & 101 & 3.85 \\
\hline 6 & W & 0.2812 & 200 & 5.48 & & \\
\hline 7 & $\mathrm{~W}$ & 0.3313 & & & 102 & 3.92 \\
\hline 8 & W & 0.3587 & $(220)(K \beta)$ & 5.50 & & \\
\hline 9 & W & & & & $(103)(\mathrm{K} \beta)$ & 3.88 \\
\hline
\end{tabular}

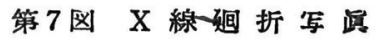

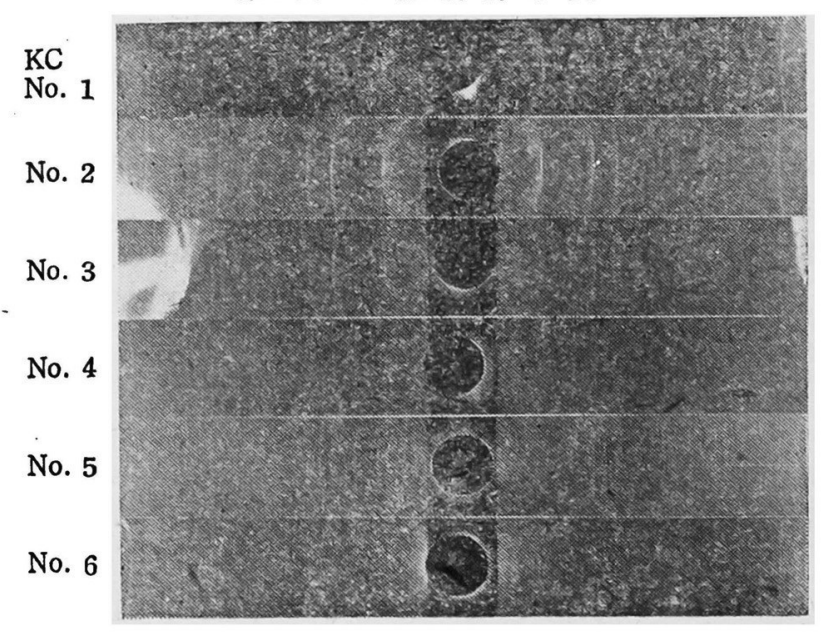

5. 結語

結晶の等方晶系之異方晶系の变化は複屈折により明かに区別せ られる所で硫化亞鉛燐光体の場合はこれに属する。これはX線の 結果とはつきり一致し，窒ろ定遗的に行い易い。その結果閃亞鉛 䣄型 $\rightarrow$ ウルッ石型の転位点は $1000^{\circ} \mathrm{C}$ よりや】高く, 大体 $1000^{\circ}$ 〜 $1050^{\circ} \mathrm{C}$ の範囲で転位の割合は $1000^{\circ} \mathrm{C}$ 附近では融剤の量に依 り変化する。これは融猎により転位点か低下する事を示す。又こ の転位点ではウルッ石型 $\rightarrow$ 閃亞鉛鉱型には速かに変化しない。粉 碎丈は压力によりゥルッ石が閊亞鉛鉱になるか如何については第 2 報に於て述べたいと思5。（昭和 22 年 4 月工化第 50 年会講 演）佾本研少は文部省科学吥究費に依つたものである。

一引用文献一

1) A. N. Winchell, Elements of Optical Mineralogy, Part. II. p. 21.

2) Schleede, Gautzckow, Z. Phys., 15, 184 (1924); A. N. Winchell, Microscopic Characters of Artificial Minerals.

3) N.Riehl, Ann. Phys., 29, 556 (1937).

- 4) W.L. Bragg, Phil. Mag., 39, 647 (1920); 牧島象二, 工化, 41, 381(1938); R.W.G.Wyckoff, The Structure of Crystals.

\title{
（131）写冠乳剂の連続的製造工程に関する研究（第 1 報）
}

\author{
菊池真一・小川 一・中野義信・大島幹義・有賀研一
}

緒

論

多くの化学工業に於ては最も経済的な製造工程として連続法を 探用している。然し写滇工業に於ては主として工程改裝置に関す る研究不足の䉆に少くとも日本にては未だ行われていない。連続 法の中でも原料を連続的に反応器へ送入しつつこれと同時に未反 応原料と生成物との混合物を反応器より取出し, 未反応原料と生 成物を分離し, 未反応原料を反応器へ戾すとい5工程が最も廣く 行われている。この工程は原料の化学反応が比較的に速かに終点 に達し, 且る原料と生成物との分離が容易な場合に適用すること が出來る。

写眞乳㶡の製造にこの連続工程を探用すると熟成器には熟成過 度の乳郕が残留するため激しい写真的かぶりを生じ, 且つ生成し た乳剤と末反応原料とを分晟する事が出來ないから製造した乳成 中には未反底原料と激しいかぶりのある乳肪とを含有している。 從つてこ5い5連続工程は写県乳㶡の製造には適用出來ないよう
に思われた。然るに著者等は次に述べるような連続的製造工程に 於て生成する乳成は種々の熟成時間を経た乳成の混合物である事 に着眼してこの混合割合を理論的に解析した。その結果意外にも 熟成過度の乳㶡は影響のない程度にしか含有されないので，から゙ りは発生せず, 且つ生成乳剤中に未反応原料が含有しても差支え ないので写真乳㶡の製造に於ても，一般化学工業に於けると同樣 に連続工程が可能であり,また回分工程に比して色々な長所があ る事が推論せられた。咼，小規模な裝置を組立て，この推論の一 部を実驗した結果, それか正しいことを確認した。

\section{理論的解析}

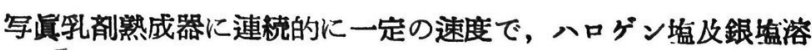

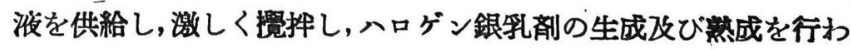
しめ, 他方湓流によつて同じ量ずつ取出す。この場合乳成の取出 量は原料送入量と同じであり, 取出乳㶡の組成は熟成器內乳刜の 組成に等しい。以下澙成器內の乳绪の解析には头の記号を用いる。 